\title{
Climatic FaCtors, RePROdUCTIVE SUCCESS AND POPULATION DYNAMICS IN THE MONTANE VOLE, MICROTUS MONTANUS
}

\section{AELITA J. PINTER $\bullet$ DEPARTMENT OF BIOLOGICAL SCIENCES UNIVERSITY OF NEW ORLEANS $\bullet$ NEW ORLEANS}

\section{$\checkmark$ OBJECTIVES}

Multiannual fluctuations in population density ("cycles") of small rodents have been known since antiquity (Elton 1942). Numerous hypotheses have been proposed to explain this phenomenon (for reviews see Finerty 1980, Taitt and Krebs 1985). However, none of these hypotheses, alone or in combination, have been able to explain the causality of cycles.

The objectives of this long-term study are to determine whether environmental variables, possibly acting through reproductive responses, contribute to the multiannual fluctuations of the montane vole, Microtus montanus.

\section{$\checkmark \quad$ METHODS}

In 1992 Microtus montanus were live trapped at two times of the year: the second half of May (spring study period) and mid-July to mid-August (summer study period). Animals were killed with an overdose of Metofane as soon as possible after capture. Animals were aged using weight, total length and pelage characteristics. Reproductive organs, the spleen and the adrenal glands were collected from all animals and preserved in Lillie's buffered neutral formalin for further histological study. Flat skins were prepared from all animals.
Population density was estimated on the basis of the trapping success in a permanent grid (established in 1970). The grid consists of 121 stations placed in a square, $5 \mathrm{~m}$ apart, 11 stations (50 m) on a side. Each station is marked with a stake. Trapping in this grid was performed only during the summer study period. One unbaited Sherman livetrap was set at each station. Additional trapping was carried out in nearby meadows to obtain additional females for litter size determination. In these areas, traps were not set in a regular pattern; rather, they were placed only in locations showing recent vole activity (cuttings, droppings).

During the spring study period trapping was carried out in a number of sites, all well removed from the permanent grid. The objective of trapping during the spring study period was to determine (on the basis of embryo size) the onset of reproduction on a population-wide basis. The reason for not trapping the grid during the spring study period was to leave the site as undisturbed as possible since the grid is the major source of information on population density.

\section{RESULTS}

For a second consecutive year Microtus montanus populations achieved very high densities at all study sides in both, optimal and marginal habitats. The high population densities attained by these 
rodents in 1992 were a consequence of a number of factors. To start with, a large number of montane voles had survived the winter. Next, during the spring study period all female $M$. montanus trapped were already pregnant. In $M$. montanus at all study sites the first litter of the year invariably becomes reproductively active in the year of its birth (Pinter 1988, Negus, Berger and Pinter 1992). Thus a very large breeding population was available early in the breeding season of 1992 . Finally there was a high reproductive success by this very large breeding population through the entire study period. Consequently, by mid-August near-record densities of M. montanus were recorded at all study sites.

A small number of meadow voles ( $M$. pennsylvanicus) was also trapped in one of the grids. Their population density remained essentially unchanged from 1991. Similarity, there appeared to be no changes in the population densities of Peromyscus maniculatus and Thomomys talpoides.

\section{$\checkmark \quad$ CONCLUSIONS}

The most noteworthy aspect of the 1992 findings is that very high densities of Microtus montanus persisted for two consecutive years at all study sites. The same situation was also observed in other parts of Wyoming, emphasizing the geographic synchrony of this phenomenon. Such geographic synchrony continues to support the hypothesis that climate plays a significant role in the population cycles of small rodents (Pinter 1988, Negus, Berger and Pinter 1992). Consequently the principal aim of this long-term study is to uncover the proximal factors (e.g., Pinter 1986, 1988, Watkins et al. 1991, Negus, Berger and Pinter 1992) that underlie these cycles.

\section{ACKNOWLEDGEMENTS}

I gratefully acknowledge the availability of the facilities and the help of the staff at the University of Wyoming-National Park Service Research Center without which it would have been impossible to accomplish this work. I am particularly grateful to the Steering Committee of the UW-NPS Research Center and to the National Park Service for their cognizance of the fact that the understanding of microtine cycles can be gained only from long-term studies.

\section{$\checkmark \quad$ LITERATURE CITED}

Elton, C.S. 1942. Voles, mice and lemmings. Clarendon Press, Oxford, 496 pp.

Finerty, J.P. 1980. The Population Ecology of Cycles in Small Mammals. Mathematic Theory and Biological Fact. Yale Univ. Press, New Haven. 234 pp.

Negus, N.C., P.J. Berger, and A.J. Pinter. 1992. Phenotypic plasticity of the montane vole (Microtus montanus) in unpredictable environments. Can. J. Zool. 70:2121-2124.

Pinter, A.J. 1986. Population dynamics and litter size of the montane vole, Microtus montanus. Can. J. of Zool. 64:1487-1490.

Pinter, A.J. 1988. Multiannual fluctuations in precipitation and population dynamics of the montane vole, Microtus montanus. Can. J. Zool. 66:2128-2132.

Taitt, M.J. and C.J. Krebs. 1985. Population dynamics and cycles In: Biology of New World Microtus. R.H. Tamarin, ed. Spec. Publ. Amer. Soc. Mammual. 8:567-620.

Watkins, R.A., S.A. Moshier, W.D. O'Dell and A.J. Pinter. 1991. Splenomegaly and reticulocytosis caused by Babesia microti infections in natural populations of the montane vole, Microtus montanus. J. Protoz. 38:573-576. 